INTERNATIONAL JOURNAL
OF
PHARMACEUTICAL SCIENCES
RESEARCH

Received on 07 May 2019; received in revised form, 01 November 2019; accepted, 27 January 2020; published 01 February 2020

\title{
DEVELOPMENT AND VALIDATION OF FTIR SPECTROSCOPIC METHOD FOR SIMULTANEOUS ESTIMATION OF TELMISARTAN AND HYDROCHLOROTHIAZIDE IN PURE AND PHARMACEUTICAL DOSAGE FORMS
}

\section{Y. Padmavathi * , Rajeswari Chilka and Revathi Tummala \\ G. Pulla Reddy College of Pharmacy, Mehdipatnam, Hyderabad - 500028, Telangana, India.}

\author{
Keywords: \\ Telmisartan, Hydrochlorothiazide, \\ FTIR, Method Validation, ICH \\ guidelines \\ Correspondence to Author: \\ Y. Padmavathi \\ G. Pulla Reddy College of Pharmacy, \\ Mehdipatnam, Hyderabad - 500028, \\ Telangana, India.
}

E-mail: drypadmavathi@gmail.com
ABSTRACT: A new analytical method has been developed for the simultaneous estimation of Telmisartan and Hydrochlorothiazide in their pure and pharmaceutical dosage forms by using Fourier Transform Infrared (FTIR) Spectroscopy. This method involves the extraction of Telmisartan and Hydrochlorothiazide from tablets using chloroform and direct measurement in liquid phase mode using reduced path length cell. The spectra were measured in absorbance mode, equipment was configured to collect spectra at $8 \mathrm{~cm}^{-1}$ resolution, and the spectra were collected between $4000 \mathrm{~cm}^{-1}$ and $450 \mathrm{~cm}^{-1}$. The infrared spectra showed different peaks with baseline correction, among which intense, clear and proportionate peaks were selected at $3411 \mathrm{~cm}^{-1}$, and $1309 \mathrm{~cm}^{-1}$ corresponding to the N-H group and asymmetric $\mathrm{SO}_{2}$ group for Telmisartan and Hydrochlorothiazide respectively for quantitative estimation. Beer-Lambert's law was obeyed over the concentration range of $50-250 \mu \mathrm{g} / \mathrm{ml}$ for Telmisartan and 25-125 $\mu \mathrm{g} / \mathrm{ml}$ for Hydrochlorothiazide. All the results were found to be within the limits. The results obtained were compared statistically with that of HPLC by t-test, which indicated no significant difference between the methods at the probability value of 0.05 . Therefore, it can be used for routine quality control of these two drugs in bulk and formulations.
INTRODUCTION: Telmisartan (TEL) is an angiotensin-II receptor antagonist used in the treatment of hypertension and chemically is $\left[1\left(1,4^{\prime}-\right.\right.$ Dimethyl-2'-propyl[2,6'-bi-1H-benzimidazol]-1'-yl) methyl]- [1, 1'- biphenyl]- 2- carboxylic acid. Angiotensin-II receptor blockers bind to the angiotensin-II type 1 receptors with high affinity, causing inhibition of the action of angiotensin II on vascular smooth muscle leading to a reduction in arterial blood pressure.

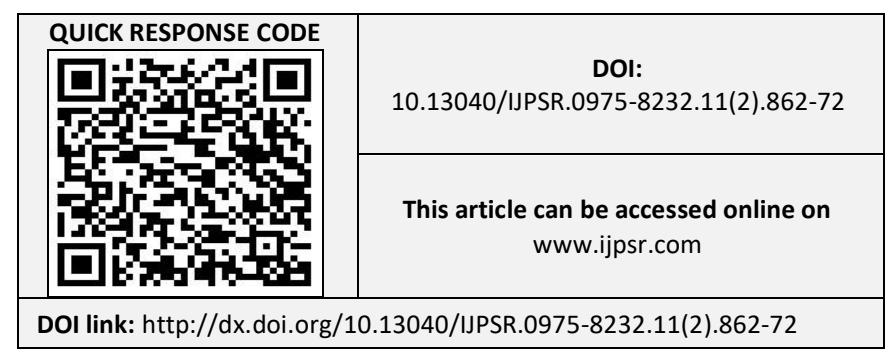

Hydrochlorothiazide (HCTZ) acts as a diuretic and chemically it is 6-chloro-3, 4-dihydro- $2 \mathrm{H}-1,2,4$ benzothiadiazine- 7- sulphonamide 1, I-dioxide. A fixed-dose combination of antihypertensive drugs can simplify dosing regimens, improve compliance, improve hypertension control, decrease dosedependent side effects and reduce cost as the firstline treatment of hypertension. The structure of Telmisartan and Hydrochlorothiazide are shown in Fig. $1^{1-3}$.

As per literature, there are several UV spectrophotometric, HPLC, and HPTLC methods used for the estimation of Telmisartan and Hydrochlorothiazide drugs alone and in combination with other drugs. There are no FTIR methods applied for the simultaneous determination of TEL and HCTZ in pure form and 
formulations as per literature ${ }^{4-20}$. FTIR methods are simple, faster and cost-effective (as there is less consumption of solvents). With this background, the work was planned to develop a method for quantitative analysis of TEL and HCTZ simultaneously in pure and combination pharmaceutical formulation, using FTIR spectrophotometric technique.
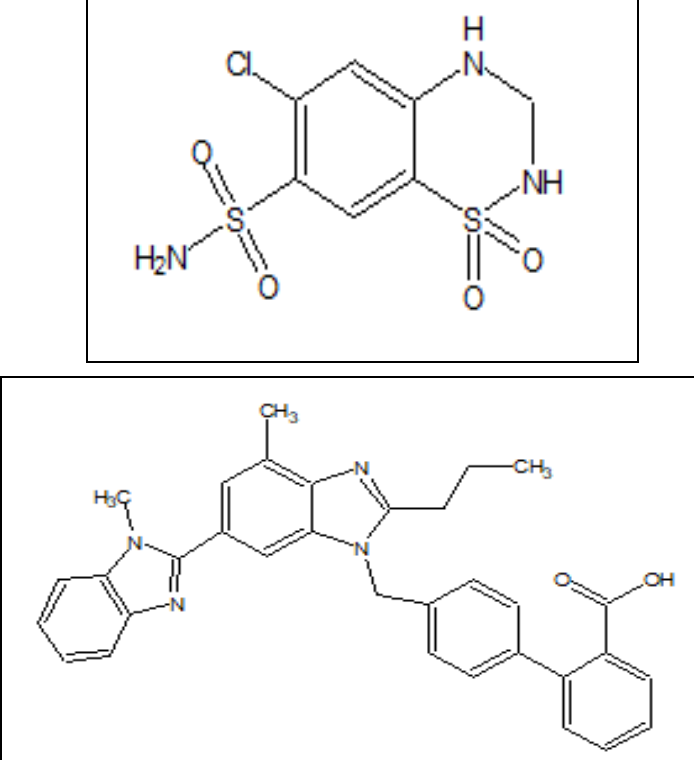

FIG. 1: STRUCTURE OF TELMISARTAN AND HYDROCHLOROTHIAZIDE

\section{MATERIALS AND METHODS:}

Reagents and Chemicals: Telmisartan was obtained as a gift sample from Dr. Reddy's laboratories and Hydrochlorothiazide from Hetero labs, Hyderabad. TELMA ${ }^{\circledR}$ tablets (Glenmark Pharmaceuticals Ltd, Sikkim) were obtained from local market. All other chemicals used were of analytical grade.

Instrumentation: FTIR instrument- Shimadzu 8400S composed of DLATGS detector, IR solution software and HPLC instrument- Shimadzu LC 20AT, with a phenomenex C-18 $(150 \mathrm{~mm} \times 4.6$ $\mathrm{mm}) \times 5 \mu \mathrm{m}$ column, with the LC solution software was used in the analysis.

Method Development: FTIR spectroscopic method was developed by using a liquid sampling technique. The following parameters were optimized during method development ${ }^{21}$.

Selection of Measurement Mode: IR spectra of TEL and HCTZ were taken in absorbance mode for quantitative analysis. Absorbances of functional peaks were measured at various wavenumbers.

Selection of Apodization: The "apodization" function is used to calculate the power spectrum through the Fourier transform of the interferogram. The apodization function gives effects on the resolution and the $\mathrm{S} / \mathrm{N}$ ratio of spectra. As the resolution increases, noise on the balance also increases. The apodization function "Happ-Genzel" was selected.

Selection of Beam: Beam parameter is used to switch the beam operation within the instrument. The parameter "internal" was selected for the measurement of the sample in the main unit.

Selection of Detector: The standard pyroelectric detector with the DLATGS element was selected.

Selection of Mirror Speed: Mirror speed " 2.8 $(\mathrm{mm} / \mathrm{sec})$ " was selected for the standard DLATGS element of the detector.

Selection of Sampling Technique: TEL is white to slightly yellowish odorless powder. HCTZ is white to off-white crystalline odorless powder. For quantitative estimation, it is difficult to prepare low concentrations of the sample by pressed pellet technique using $\mathrm{KBr}$. Therefore, a liquid sampling technique was used. The solutions were prepared in a suitable IR solvent and were analyzed by using fixed path length liquid cells. The liquid drop forms a thin film between the two sodium chloride plates.

Solvent Selection: Suitable solvent was selected based on the solubility profile of the drug and IR transparency window of the solvent. They were found to be freely soluble in non-polar solvents like chloroform, cyclohexane, dimethylformamide and dimethyl sulfoxide (DMSO). Chloroform is transparent throughout the region of $800-5000 \mathrm{~cm}^{-1}$; Cyclohexane is transparent in the IR window of $1500-2500 \mathrm{~cm}^{-1}, 1100-1200 \mathrm{~cm}^{-1}, 700-840 \mathrm{~cm}^{-1}$. Therefore, Chloroform was selected as a suitable solvent for the quantitative estimation of TEL and HCTZ. The primary stock solutions of the two drugs were prepared in DMSO.

IR Spectra Analysis for Functional Group Assessment: IR spectra of TEL and HCTZ taken in absorbance mode were analyzed and functional 
group peaks whose absorbance showed a proportionate increase in absorbance with an increase in conc. were selected for the quantitation of two drugs.

\section{Preparation of Standard Solutions:}

Telmisartan and Hydrochlorothiazide Standard Solutions: $12.5 \mathrm{mg}$ of TEL and $10 \mathrm{mg}$ of HCTZ were weighed separately and transferred into a 25 $\mathrm{ml}$ volumetric flask containing $2 \mathrm{~mL}$ of DMSO. The contents were sonicated for $5 \mathrm{~min}$ and the volume was made up with chloroform.

Sample Preparation: Twenty tablets (containing $40 \mathrm{mg}$ of TEL and $12.5 \mathrm{mg}$ of HCTZ) were weighed and finely powdered. The powder equivalent to $25 \mathrm{mg}$ of HCTZ was weighed and transferred to a $25 \mathrm{~mL}$ volumetric flask containing $10 \mathrm{~mL}$ of DMSO and sonicated for $30 \mathrm{~min}$ and the volume was made up with chloroform. The solution was centrifuged at $3000 \mathrm{rpm}$ for $15 \mathrm{~min}$ and filtered through Whatman filter paper.

Method Validation: The developed method was validated according to the ICH guidelines Q2 (R1): Validation of Analytical Procedures: Text and Methodology ${ }^{22}$ for the following parameters:

Linearity and Range: A series of standard solutions of TEL and HCTZ were prepared in the concentration range of 50- $250 \mu \mathrm{g} / \mathrm{mL}$ and $25-125$ $\mu \mathrm{g} / \mathrm{mL}$ respectively. Each of the working standard solutions of TEL and HCTZ was injected into the liquid sample cell and analyzed in the FTIR instrument.

The absorbance of the peaks at $3411.84 \mathrm{~cm}^{-1}$ and $1309.58 \mathrm{~cm}^{-1}$ were recorded for standard solutions. Standard calibration curves were plotted between concentration and absorbance ranges. Linearity was established by regression analysis; regression equation and coefficient of determination were reported.

Limit of Detection (LOD) and Limit of Quantification (LOQ): The sensitivity of the proposed method for measurement of Telmisartan and Hydrochlorothiazide was estimated in terms of LOD \& LOQ, determined using standard deviation method. Standard deviation and slope were calculated from the calibration curve established for linearity.
Sandell's Sensitivity: Telmisartan $(50 \mu \mathrm{g} / \mathrm{ml})$ and Hydrochlorothiazide $(25 \mu \mathrm{g} / \mathrm{ml})$ were prepared and scanned. Sandell's sensitivity was calculated from the measured absorbance values using the formula given below.

Sandell's Sensitivity (л) $=$ Concentration $(\mu \mathrm{g} / 100 \mathrm{ml}) \times$ 0.001/absorbance value

Precision: The precision of the method was established by reporting repeatability and intermediate precision. The standard deviation (SD) or percentage relative standard deviation (\% RSD) of a series of measurements is usually used to assess the precision of an analytical method. Only one stage of precision was calculated. Repeatability was determined by analyzing 6 replicates of 100 $\mu \mathrm{g} / \mathrm{mL} \& 75 \mu \mathrm{g} / \mathrm{mL}$ concentration of TEL \& HCTZ respectively. The $\% \mathrm{RSD}$ was calculated. The results obtained are shown in Table 4.

Accuracy (Recovery study): The accuracy of an analytical method describes the extent to which the test results deviate from the expected results. It is also described as a measure of the exactness of an analytical method. Accuracy along with precision is said to determine the error associated with an analytical method and therefore, these are important criteria for the evaluation of suitability of an analytical method of the task for which it is intended. The accuracy of the developed method for drug products was determined by using the standard addition method. To 100, 150 and 200 $\mu \mathrm{g} / \mathrm{mL}$ Hydrochlorothiazide and 50, 100 and 150 $\mu \mathrm{g} / \mathrm{mL}$ of Telmisartan, $5 \mathrm{~mL}$ of respective standard solution $(50 \mu \mathrm{g} / \mathrm{mL})$ were added. The prepared solutions were analyzed thrice and absorbance of peaks was recorded at $3411.84 \mathrm{~cm}^{-1}$ and 1309.58 $\mathrm{cm}^{-1}$ for Telmisartan and Hydrochlorothiazide and respectively. The results obtained are shown in Tables 5 and 6.

Assay of Telmisartan and Hydrochlorothiazide Tablets: Twenty tablets containing $40 \mathrm{mg}$ of TEL and $12.5 \mathrm{mg}$ of HCTZ were weighed and finely powdered. The powder equivalent to $25 \mathrm{mg}$ of HCTZ was weighed and transferred to a $25 \mathrm{~mL}$ volumetric flask containing $10 \mathrm{~mL}$ of DMSO and sonicated for $30 \mathrm{~min}$. The flask was shaken and volume was made up to $25 \mathrm{ml}$ with chloroform to obtain a solution of $1000 \mu \mathrm{g} / \mathrm{mL}$. The solution was centrifuged at $3000 \mathrm{rpm}$ for $15 \mathrm{~min}$ and filtered. 
$100 \mu \mathrm{g} / \mathrm{mL}$ solutions were prepared from a sample stock solution. The amount of drug present in each tablet was calculated using the formula given below.

$\%$ Assay $=$ Concentration $(\mu \mathrm{g} / \mathrm{mL} \times$ Dilution factor $\times$ Average weight of the tablet $(\mathrm{mg}) \times 100 /$ Weight of the tablet powder taken $\mathrm{mg} \times$ Label claim of the drug

Analysis by HPLC Method: Quantitative estimation by FTIR is a new technique and the data obtained needs to be compared with that of significant quantitative analytical techniques like High-Performance Liquid Chromatography or UVVisible spectroscopy. The results obtained by FTIR by this technique were compared statistically with the results by HPLC for quantitation of Telmisartan and Hydrochlorothiazide.

A number of analytical methods have been reported in the literature for the simultaneous estimation of Telmisartan and Hydrochlorothiazide in tablets. A reverse HPLC method previously developed and validated by Gopala Swamy et al., was used for comparing the results obtained by this new FTIR method for estimation of Telmisartan and Hydrochlorothiazide.

Instrumentation: A gradient high-performance liquid chromatography (SHIMADZU), HPLC pump LC-20AT, with LC solutions software, UVvisible detector SPD-20A, C-18column $(250 \times$ $4.6 \mathrm{~mm}, 5 \mu \mathrm{m})$ was used.

TABLE 1: CHROMATOGRAPHIC CONDITIONS

\begin{tabular}{cc}
\hline Mobile & Buffer $(\mathbf{p H ~ 3 . 0 )}:$ \\
Phase & Acetonitrile (60:40) \\
\hline Column & Enable-C $18,5 \mu \mathrm{m}$ \\
Flow rate & $0.8 \mathrm{~mL} / \mathrm{min}$ \\
Detection wavelength & $271 \mathrm{~nm}$ \\
Injection volume & $20 \mu 1$ \\
Column oven temperature & $25^{\circ} \mathrm{C}$ \\
Run time & $20 \mathrm{~min}$ \\
Retention times & $7.78 \mathrm{~min} \& 3.84 \mathrm{~min}$ for TEL \\
& \& HCTZ \\
\hline
\end{tabular}

A series of standard solutions were prepared in the concentration range $10-50 \mu \mathrm{g} / \mathrm{mL}$ by transferring required volumes of stock solutions of two drugs. $20 \mu \mathrm{l}$ of a combination of these working standard solutions of Telmisartan and Hydrochlorothiazide were injected into the HPLC. Retention time and peak area were recorded. The calibration curve was constructed between concentration and peak area.
Assay of Telmisartan and Hydrochlorothiazide Tablets by HPLC: Twenty tablets were weighed and finely powdered. The powder equivalent to 25 mg of HCTZ was weighed and transferred to 25 $\mathrm{mL}$ volumetric flask containing $10 \mathrm{~mL}$ of DMSO and sonicated. The volume was made up to $25 \mathrm{ml}$ with methanol. The solution was centrifuged at $3000 \mathrm{rpm}$ for $15 \mathrm{~min}$ and filtered through a $0.22 \mu \mathrm{m}$ syringe filter. The sample solution was injected into the HPLC. Tablet sample concentration was calculated from the calibration curve. The percentage of purity was calculated by using the following formula.

Assay $=$ Concentration $(\mu \mathrm{g} / \mathrm{mL}) \times$ Dilution factor $\times$ Average weight of the tablet $(\mathrm{mg}) \times 100 /$ Weight of the tablet powder taken $(\mathrm{mg}) \times$ Label claim of the drug

\section{Comparison of Results of FTIR and HPLC:}

Null Hypothesis: There was no significant difference between results obtained from the two different methods.

t-test: The t-test was performed to prove that there is no significant difference between the recovery values of new FTIR and the existing HPLC method. t-test for paired samples was performed on the data of two methods: FTIR and HPLC. The calculated t-value was compared with the tabulated $\mathrm{t}$-value at a p-value of 0.05 . If the calculated t-value is less than tabulated the null hypothesis is accepted 23. The t-value was calculated by using the following formula:

$\mathrm{t}=$ Mean of the difference between the paired values / Standard error of the difference

RESULTS AND DISCUSSION: The new FTIR method was developed for quantitation of Telmisartan and Hydrochlorothiazide in tablet formulation by using a liquid sampling technique. The FTIR spectrum of pure TEL and HCTZ was taken using a pressed pellet technique which exhibited numerous well-defined bands. However, the presence of high quantities of lactose and cellulose (used as excipients in the pharmaceutical formulations) prevented the direct determination of drugs using a pressed pellet technique.

Therefore, the previous separation of the active principle from the samples is required. The drug was extracted from the tablets using chloroform 
and IR analysis was carried out in chloroform solution using a liquid sampling technique.

FTIR method was optimized using the following instrumental conditions shown in Table 2.

\section{TABLE 2: OPTIMIZED FTIR CONDITIONS}

\begin{tabular}{cc}
\hline Measurement mode & Absorbance mode \\
\hline Apodization & Happ-Genzel \\
Solvent & Chloroform \\
Frequency Range & $400-4000 \mathrm{~cm}^{-1}$ \\
Number of Scans & 45 \\
Resolution & $8.0 \mathrm{~cm}^{-1}$ \\
\hline
\end{tabular}

Based on drug solubility, chloroform and dimethyl chloride were selected as solvents for taking IR spectra by liquid sampling technique. In chloroform, better peak intensity was observed (as chloroform is transparent throughout the region of $800-5000 \mathrm{~cm}^{-1}$ ). Hence chloroform was selected as a solvent. The mid-IR region $\left(400-4000 \mathrm{~cm}^{-1}\right)$ was selected as the frequency range. 45 scans were selected for better $\mathrm{S} / \mathrm{N}$ ratio; as a number of scans increases, $\mathrm{S} / \mathrm{N}$ ratio increases. A resolution was set to $8 \mathrm{~cm}^{-1}$ for better peak-to-peak separation.

IR spectra of standard TEL and HCTZ obtained by pressed pellet technique using KBr Fig. 2 and $\mathbf{3}$ and by liquid sampling technique in chloroform Fig. 4, 5 and 6 respectively.

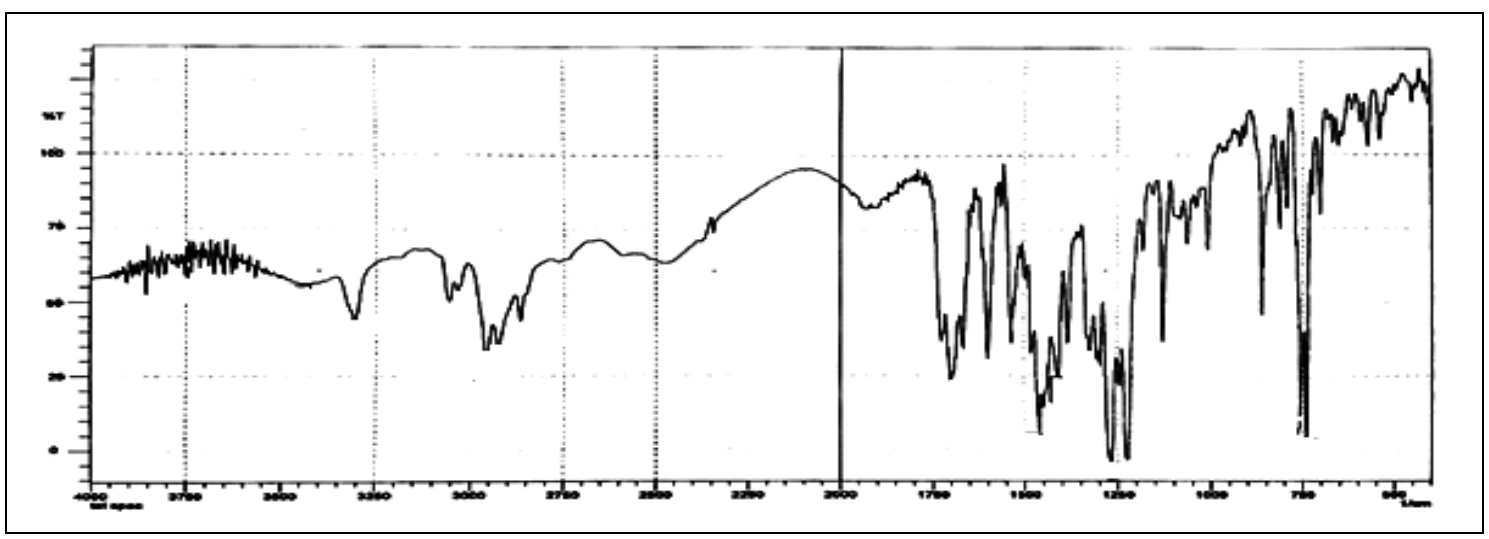

FIG. 2: FTIR SPECTRUM OF PURE TELMISARTAN IN TRANSMISSION MODE

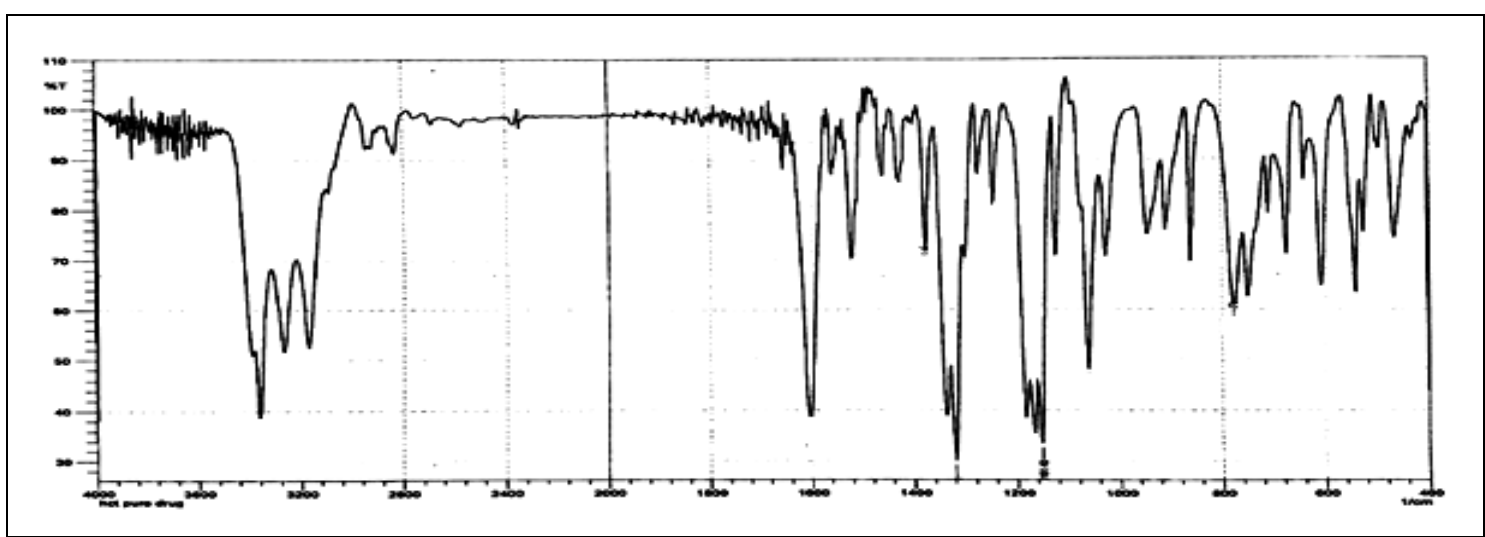

FIG. 3: FTIR SPECTRUM OF PURE HYDROCHLOROTHIAZIDE IN TRANSMISSION MODE

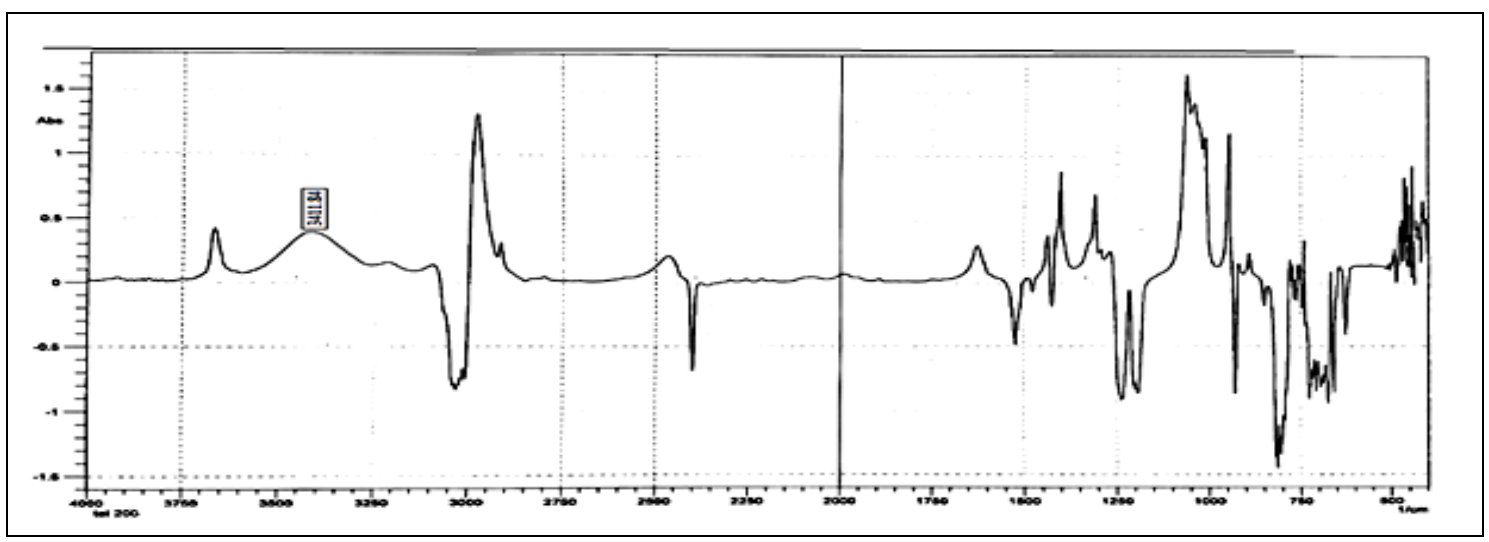

FIG. 4: FTIR SPECTRUM OF TELMISARTAN IN CHLOROFORM BY LIQUID SAMPLING TECHNIQUE 


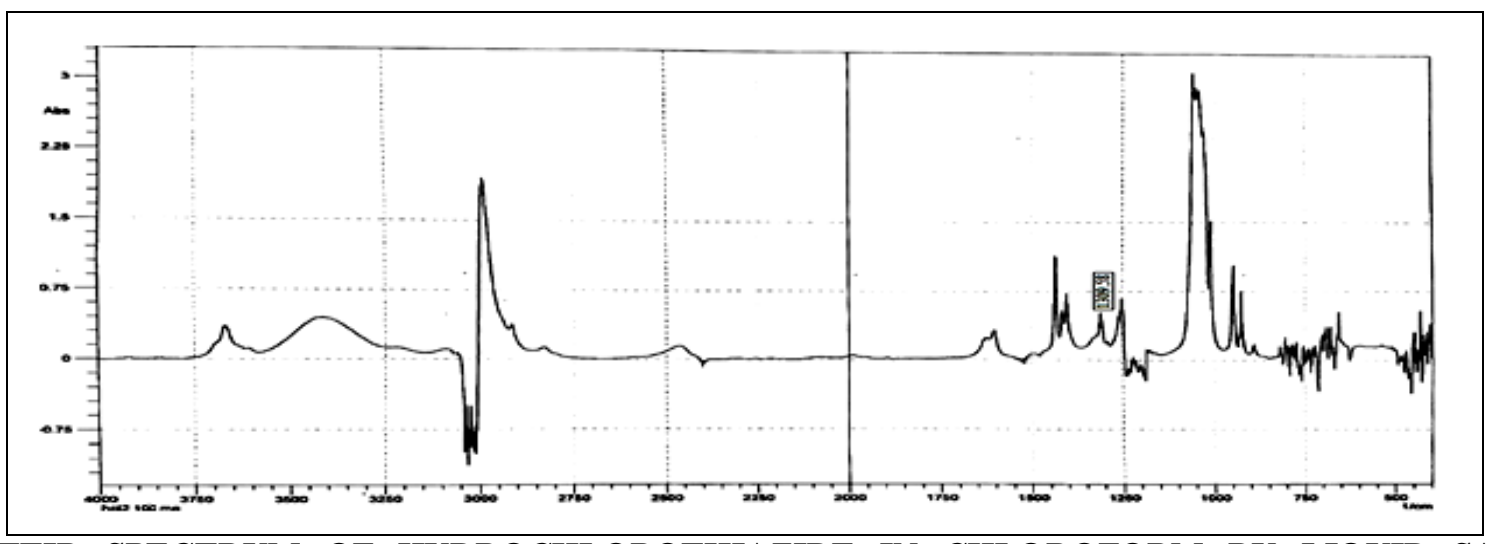

FIG. 5: FTIR SPECTRUM OF HYDROCHLOROTHIAZIDE IN CHLOROFORM BY LIQUID SAMPLING TECHNIQUE (ABSORBANCE MODE)

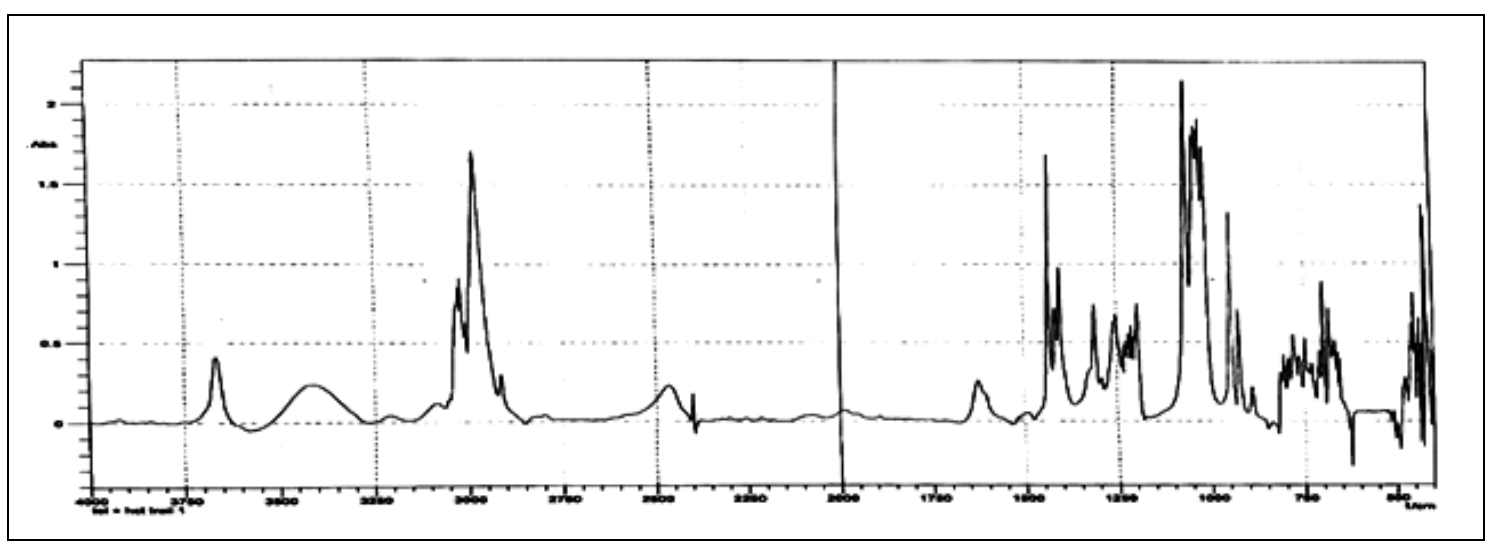

FIG. 6: FTIR SPECTRUM OF TELMISARTAN AND HYDROCHLOROTHIAZIDE IN COMBINATION BY LIQUID SAMPLING TECHNIQUE (ABSORBANCE MODE)

IR spectrum of Telmisartan showed peaks at 1700 $\mathrm{cm}^{-1}, 3000 \mathrm{~cm}^{-1}, 3400 \mathrm{~cm}^{-1}$ correspondings to the carbonyl group, $\mathrm{N}-\mathrm{H}$ group and $\mathrm{O}-\mathrm{H}$ group respectively. Among which $\mathrm{O}-\mathrm{H}$ group showed a clear, intense peak that increased linearly as the concentration increased. It was selected for the quantitative analysis of Telmisartan.

Hydrochlorothiazide IR spectrum gave peaks at $1185 \mathrm{~cm}^{-1}, 1310 \mathrm{~cm}^{-1}, 3200 \mathrm{~cm}^{-1}$ corresponding to $\mathrm{SO}_{2}$ asymmetric stretching, $\mathrm{SO}_{2}$ symmetric stretching and $\mathrm{N}-\mathrm{H}$ group respectively. Among these, the $\mathrm{SO}_{2}$ group showed a clear, intense peak which increased linearly as the concentration increased.
It was selected for the quantitative analysis of Hydrochlorothiazide. All the calculated values for validation parameters were found to be within acceptable limits.

A linear and proportional relationship was observed between the concentration and absorbance in the range of $50-250 \mu \mathrm{g} / \mathrm{mL}$ for TEL and $25-125 \mu \mathrm{g} / \mathrm{mL}$ for HCTZ. This is used for the quantitation of drugs in pure and formulations. The linearity of the method was established by performing linear regression analysis for the calibration curve constructed between concentration and absorbance as shown in Table 3.

TABLE 3: STANDARD CALIBRATION CURVE DATA FOR TEL AND HCTZ

\begin{tabular}{|c|c|c|c|c|}
\hline \multirow[t]{2}{*}{ S. no. } & \multicolumn{2}{|c|}{ Telmisartan (TEL) } & \multicolumn{2}{|c|}{ Hydrochlorothiazide (HCTZ) } \\
\hline & $\begin{array}{c}\text { Concentration } \\
(\mu \mathrm{g} / \mathrm{mL})\end{array}$ & $\begin{array}{c}\text { Absorbance } \\
\text { at } 3411.84 \mathrm{~cm}^{-1}\end{array}$ & $\begin{array}{c}\text { Concentration } \\
(\mu \mathrm{g} / \mathrm{mL})\end{array}$ & $\begin{array}{c}\text { Absorbance } \\
\text { at } 1309.58 \mathrm{~cm}^{-1}\end{array}$ \\
\hline 1 & 50 & 0.1230 & 25 & 0.131 \\
\hline 2 & 100 & 0.2497 & 50 & 0.2544 \\
\hline 3 & 150 & 0.3526 & 75 & 0.3964 \\
\hline 4 & 200 & 0.4769 & 100 & 0.5241 \\
\hline 5 & 250 & 0.5963 & 125 & 0.6536 \\
\hline
\end{tabular}

*Average of three determinations 

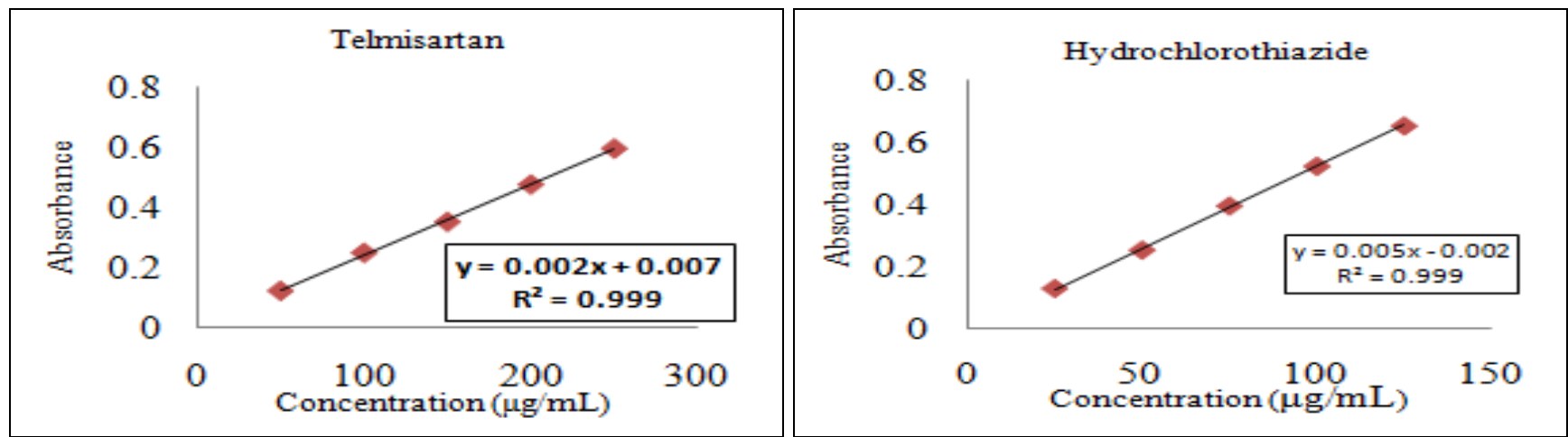

FIG. 7: STANDARD CALIBRATION CURVE OF TELMISARTAN AND HYDROCHLOROTHIAZIDE

The response of TEL and HCTZ was found to be linear in the investigational concentration range. Fig. 8, 9, 10, and 11. For these studies, obtained $r^{2}$ value was considered to be appropriate to demonstrate the linearity of the method as shown in Fig. 7.

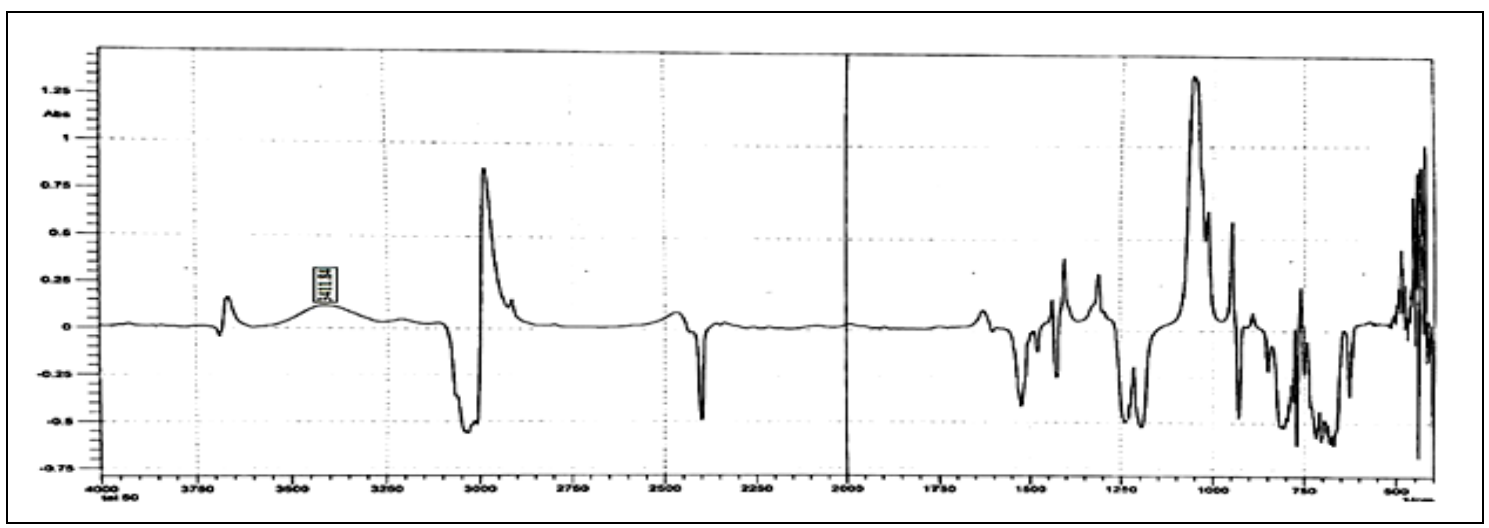

FIG. 8: FTIR SPECTRUM OF TEL STANDARD [50 $\mu \mathrm{g} / \mathrm{mL}]$

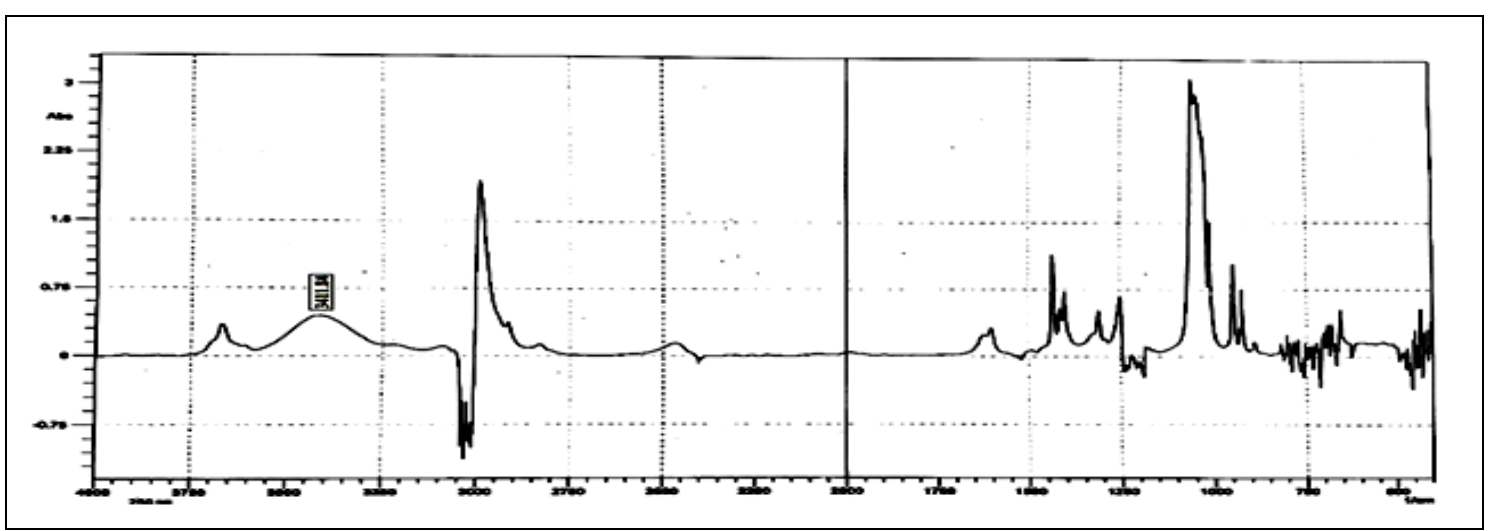

FIG. 9: FTIR SPECTRUM OF TEL STANDARD [250 $\mu \mathrm{g} / \mathrm{mL}]$

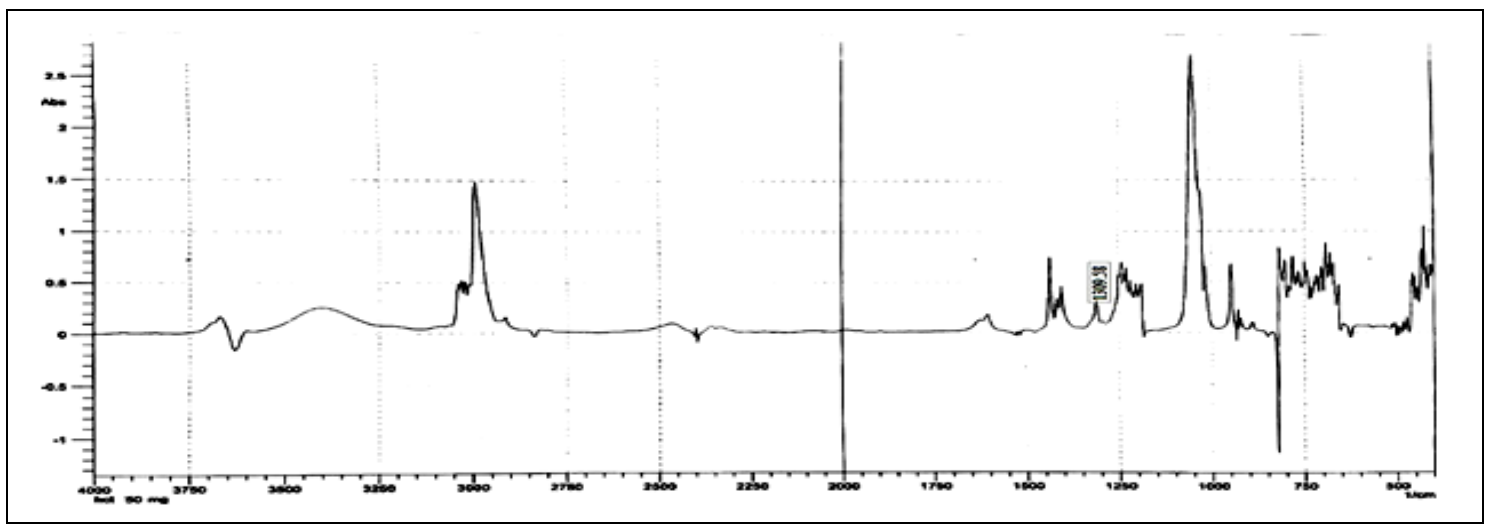

FIG. 10: FTIR SPECTRUM OF HCTZ STANDARD [50 $\mu \mathrm{g} / \mathrm{mL}]$ 


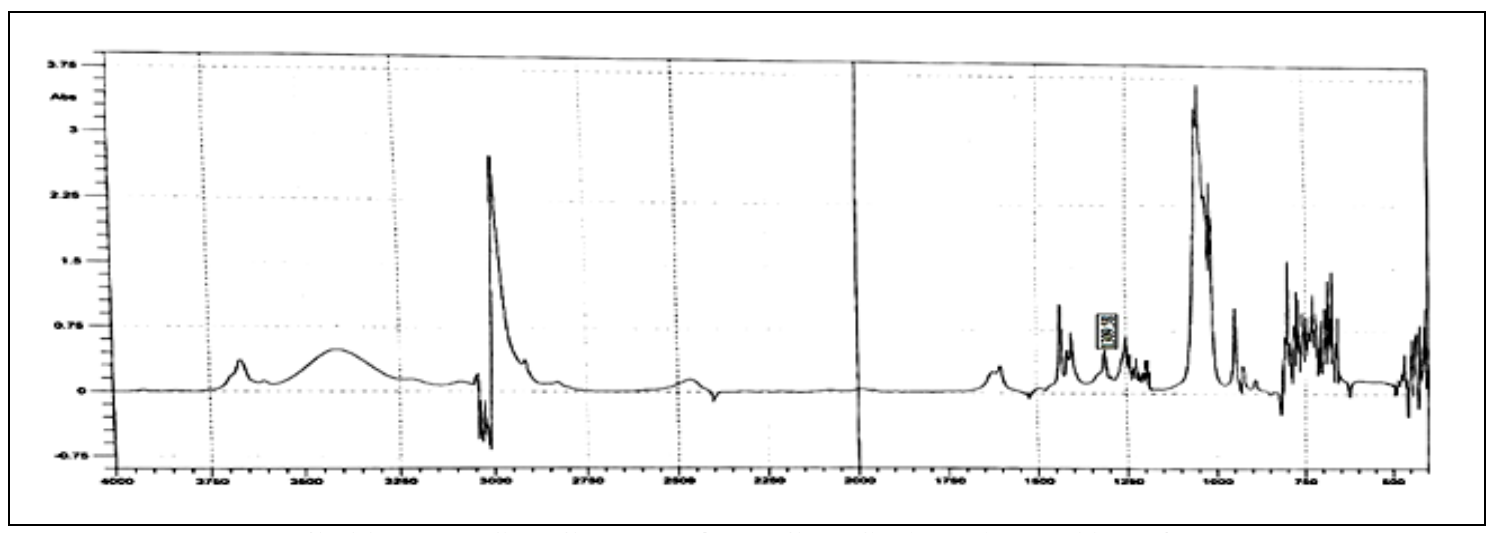

FIG. 11: FTIR SPECTRUM OF HCTZ STANDARD [125 $\mu \mathrm{g} / \mathrm{mL}]$

TABLE 4: REPEATABILITY DATA

\begin{tabular}{ccc}
\hline S. no. & \multicolumn{2}{c}{ Absorbance } \\
\cline { 2 - 3 } & TEL & HCTZ \\
\hline 1 & 0.2544 & 0.32 \\
2 & 0.2503 & 0.3226 \\
3 & 0.2549 & 0.3119 \\
4 & 0.2562 & 0.3271 \\
5 & 0.2554 & 0.3284 \\
6 & 0.2506 & 0.3217 \\
Mean ${ }^{*} \pm$ SD & $0.2536 \pm 0.002538$ & $0.3219 \pm 0.005889$ \\
$\%$ RSD & 1.00 & 1.829 \\
\hline
\end{tabular}

Repeatability results obtained for six replicates of standard solutions of TEL and HCTZ are shown in Table 4.
As all the determined observations were close to one another, and the deviation was found to be negligible; the proposed method is deemed to be precise in terms of repeatability.

The accuracy of the method was reported by carrying out recovery studies. Results proved that the method was accurate to quantify TEL and HCTZ in tablets. These results are shown in Tables 5 and $\mathbf{6}$ with the corresponding IR spectra shown in Fig. 12.

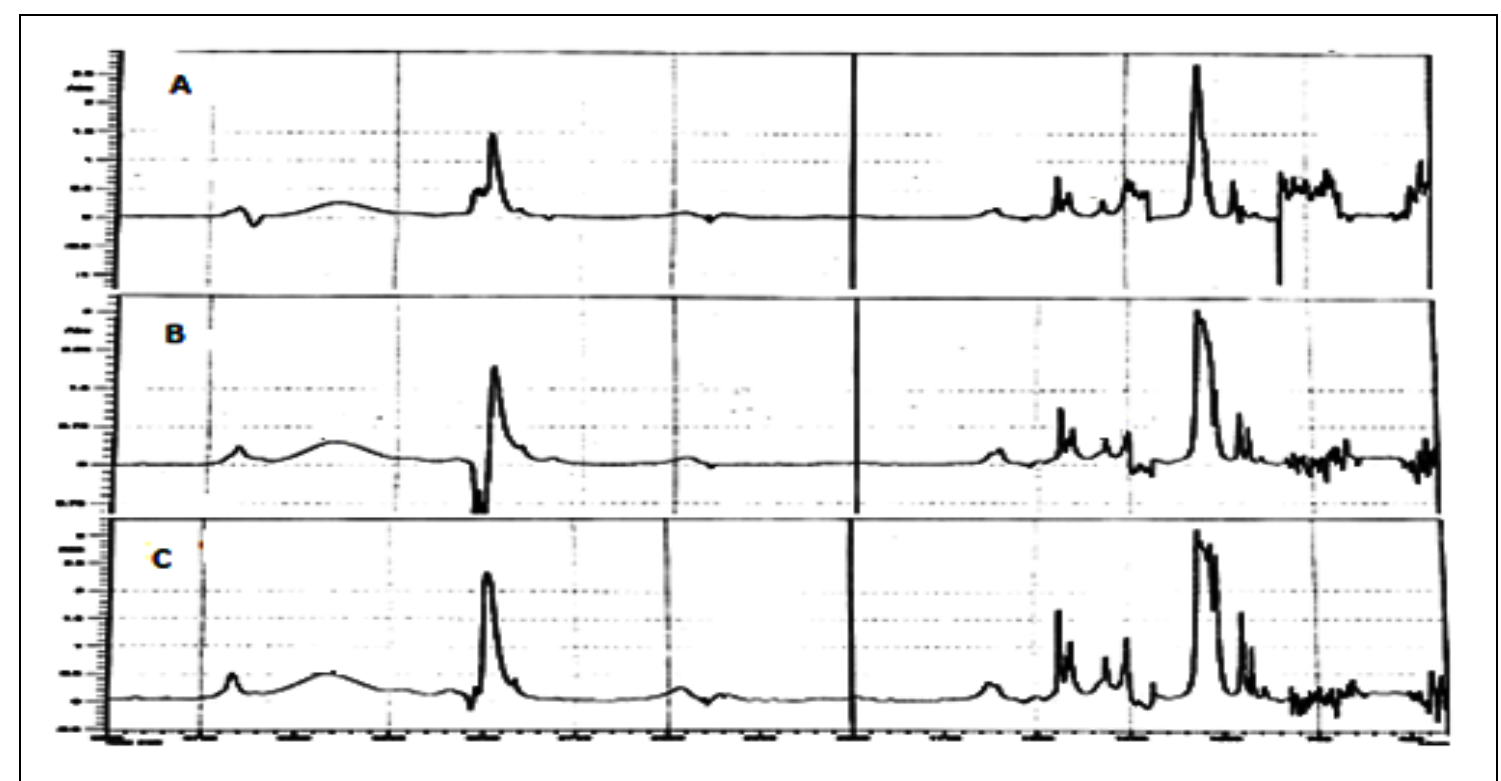

FIG. 12: FTIR SPECTRA FOR RECOVERY STUDIES FOR FORMULATION AT THREE LEVELS: A- 75\%, B $100 \%, \mathrm{C}-125 \%$

TABLE 5: RECOVERY STUDIES DATA FOR DRUG PRODUCT (TELMISARTAN)

\begin{tabular}{ccccccc}
\hline $\begin{array}{c}\text { Recovery } \\
\text { Level } \\
\boldsymbol{\%}\end{array}$ & $\begin{array}{c}\text { Concentration } \\
\text { of Sample } \\
(\boldsymbol{\mu g} / \mathbf{m L})\end{array}$ & $\begin{array}{c}\text { Amount of } \\
\text { Standard Added } \\
(\boldsymbol{\mu g} / \mathbf{m L})\end{array}$ & $\begin{array}{c}\text { Absorbance } \\
\mathbf{A}\end{array}$ & $\begin{array}{c}\text { Concentration } \\
\text { Recovered } \\
(\boldsymbol{\mu g} / \mathbf{m L})\end{array}$ & $\begin{array}{c}\text { \% } \\
\text { Recovery }\end{array}$ & $\begin{array}{c}\text { Mean } \\
\mathbf{\%} \text { RSD }\end{array}$ \\
\hline $75 \%$ & 100 & 50 & 0.3821 & 150.25 & 100.16 & \\
$100 \%$ & 150 & 50 & 0.4162 & 199.60 & 99.8 & $100.22 / 0.4626$ \\
$125 \%$ & 200 & 50 & 0.5206 & 251.80 & 100.72 & \\
\hline
\end{tabular}

* Average of 3 determinations 
TABLE 6: RECOVERY STUDIES DATA FOR DRUG PRODUCT (HYDROCHLOROTHIAZIDE)

\begin{tabular}{ccccccc}
\hline $\begin{array}{c}\text { Recovery } \\
\text { Level } \\
\boldsymbol{\%}\end{array}$ & $\begin{array}{c}\text { Concentration } \\
\text { of Sample } \\
(\boldsymbol{\mu g} / \mathbf{m L})\end{array}$ & $\begin{array}{c}\text { Concentration of } \\
\text { Standard Added } \\
(\boldsymbol{\mu g} / \mathbf{m L})\end{array}$ & $\begin{array}{c}\text { Absorbance } \\
\mathbf{A}\end{array}$ & $\begin{array}{c}\text { Concentration } \\
\text { Recovered } \\
(\boldsymbol{\mu g} / \mathbf{m L})\end{array}$ & $\begin{array}{c}\text { \% } \\
\text { Recovery }\end{array}$ & $\begin{array}{c}\text { Mean } / \\
\mathbf{\%} \text { RSD }\end{array}$ \\
\hline $75 \%$ & 50 & 25 & 0.3775 & 75.9 & 100.48 & \\
$100 \%$ & 75 & 25 & 0.5002 & 100.44 & 100.44 & $100.48 / 0.0507$ \\
$125 \%$ & 100 & 25 & 0.6264 & 125.68 & 100.54 & \\
\hline
\end{tabular}

* Average of 3 determinations

Assay: The FTIR method was used for the analysis of marketed formulations and their results were found to be within the limits, as shown in Table 7 and Fig. 13.

TABLE 7: ASSAY RESULTS OF MARKETED FORMULATIONS

\begin{tabular}{cccccc}
\hline Brand Name & Drug & Label Claim & Drug Content $^{*}$ & Assay $(\%)^{*} \pm$ SD & \% RSD \\
\hline TELMA H $^{\circledR}$ & TEL & $40 \mathrm{mg}$ & $40.108 \mathrm{mg}$ & $100.27 \pm 0.25006$ & 0.647 \\
& HCTZ & $12.5 \mathrm{mg}$ & $12.04 \mathrm{mg}$ & $96.32 \pm 0.7546$ & 1.85 \\
\hline
\end{tabular}

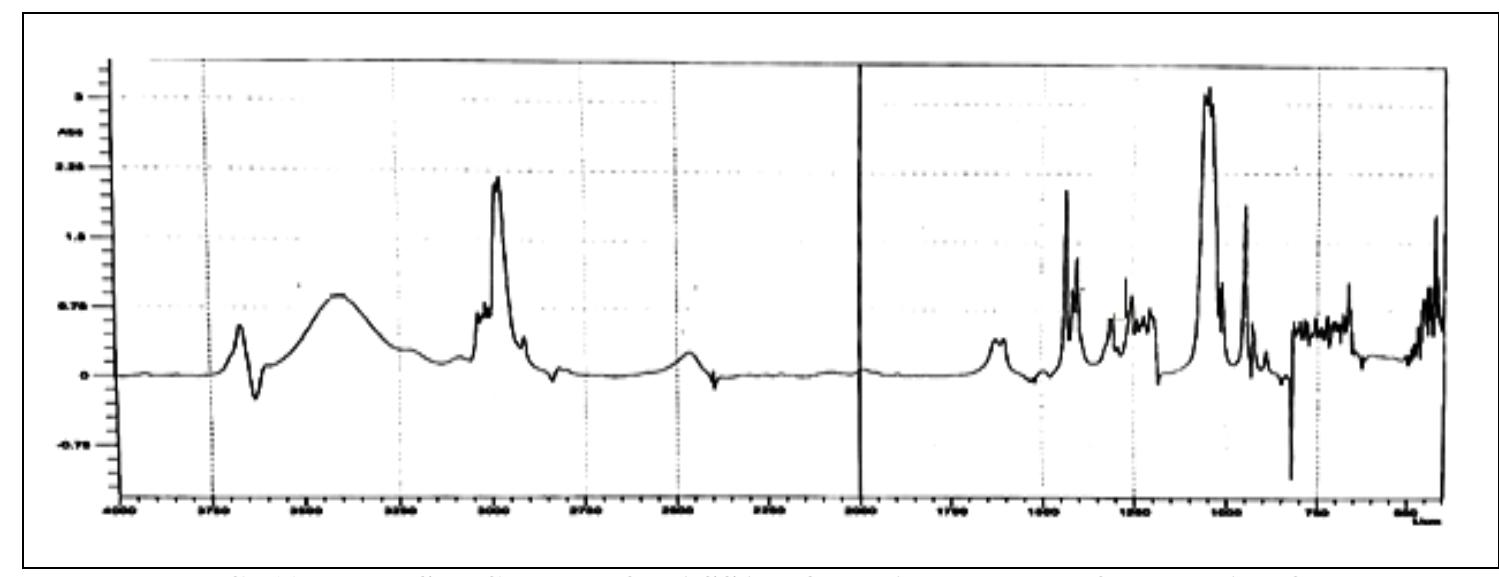

FIG. 13: FTIR SPECTRUM OF ASSAY OF MARKETED FORMULATION

As the FTIR method is a new method for quantitative analysis of these drugs, the results were compared with that of the validated HPLC method using a t-test. The sample concentration was calculated by using the calibration model generated in the concentration range of 10-50 $\mu \mathrm{g} / \mathrm{mL}$. The sample chromatogram is shown in Fig. 14.

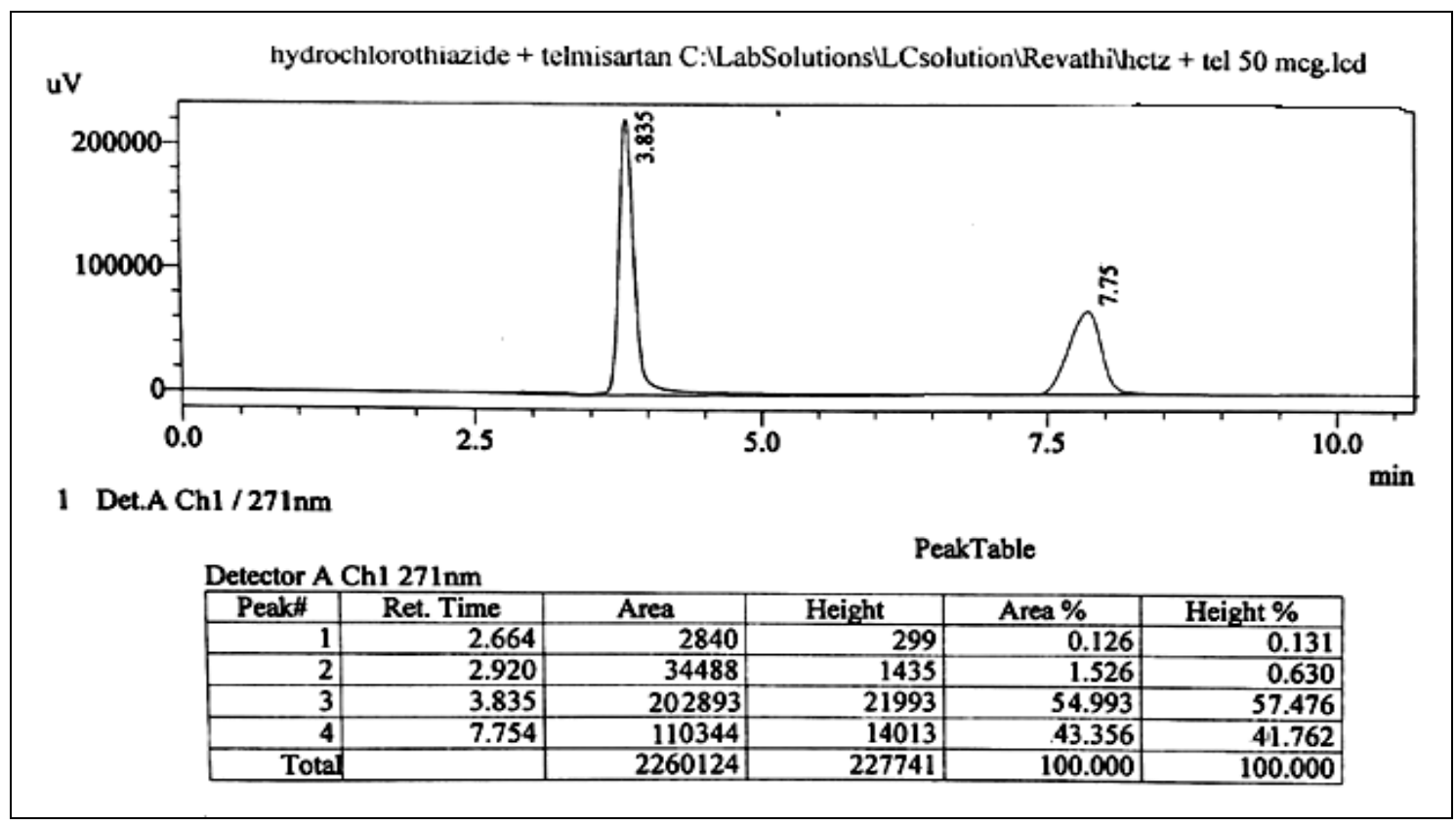

FIG. 14: CHROMATOGRAM OF ASSAY OF MARKETED FORMULATION 
Comparison of Results of FTIR and Results of HPLC: The recovery values of FTIR and HPLC methods were compared by applying a t-test for paired samples. The data is shown in Table 8. t-test was performed considering the null hypothesis to be true i.e., there is no significant difference in the recovery values of the new FTIR method and the existing HPLC method as shown in Table 8.

TABLE 8: t- TEST DATA

\begin{tabular}{cccccc}
\hline Trial & Drug & FTIR \% Recovery $\left(\mathbf{X}_{\mathbf{1}}\right)$ & HPLC \% Recovery $\left(\mathbf{X}_{\mathbf{2}}\right)$ & Difference $\left(\mathbf{X}_{\mathbf{1}}-\mathbf{X}_{\mathbf{2}}=\mathbf{d}\right)$ & $\left(\mathbf{X}_{\mathbf{1}}-\mathbf{X}_{\mathbf{2}}\right)^{2}=\mathbf{d}^{\mathbf{2}}$ \\
\hline 1 & TEL & 99.128 & 100.01 & -0.882 & 0.777924 \\
& HCTZ & 100.06 & 100.129 & -0.069 & 0.004761 \\
2 & TEL & 100.426 & 99.979 & 0.447 & 0.199809 \\
& HCTZ & 100.29 & 99.986 & 0.304 & 0.092416 \\
3 & TEL & 101.106 & 99.849 & 1.257 & 1.580049 \\
& HCTZ & 101.09 & 99.912 & 1.178 & 1.387684 \\
& & & $\Sigma d=2.235$ & $\Sigma d^{2}=4.99522$ \\
\hline
\end{tabular}

Where $\Sigma \mathrm{d}$ is mean of the difference between paired values; $\Sigma \mathrm{d}^{2}$ is the standard error of the difference

The calculated t-value was 0.9170 and the tabulated $\mathrm{t}$-value at $\mathrm{P}=0.05$ was 1.943 . The calculated $\mathrm{t}$-value was found to be lesser than the tabulated t-value. This clearly indicated that the two recovery values were quite similar.

Therefore, the null hypothesis stating that there is no significant difference between the recovery values of two methods: Proposed FTIR method and the Existing HPLC method; was accepted at $\mathrm{P}=0.05$. The difference between the recovery values of the two methods was not a real difference because the level of significance was very low.

CONCLUSION: The primary use of FTIR in the transmission mode, as referenced in all compendium pharmacopeias is for the identification of functional groups in raw materials and finished products. FTIR technique is seldom used for quantitative analysis. In this study, a new FTIR method was developed for determining Telmisartan and Hydrochlorothiazide. The method fulfilled most validation requirements in a range of concentrations suitable for quality control of both drugs in their pure and solid dosage forms. The developed method was compared with the HPLC method and was found to be equally significant. In addition, the FTIR method reduces solvent consumption and eliminates the usage of reagents.

\section{ACKNOWLEDGEMENT: Nil}

\section{CONFLICTS OF INTEREST: Nil}

\section{REFERENCES:}

1. Maryadele JON: The Merck Index, $13^{\text {th }}$ Edition, Merck Research Lab publishers, White House Station, NJ, US, 2001; 989(5538): 854(4802).
2. Tripathi KD: Essentials of Medical Pharmacology, $6^{\text {th }}$ Edition, Jaypee Brothers Medical publishers Ltd, New Delhi 2010: 485-40.

3. Rang HP, Dale MM, Ritter JM, Flower RJ and Henderson G: Pharmacology. $7^{\text {th }}$ edition. Spain: Elsevier Churchil livingstone 2012.

4. Padmavathi Y, Akari A, N Babu NR and Kumar PR: Development and validation of new FTIR method for quantitative analysis of gliclazide in bulk and pharmaceutical dosage forms. Asian J Research Chem 2017; 10(3).

5. Reddy NR, Padmavathi Y, Mounika P and Akari A: FTIR spectroscopy for estimation of efavirenz in raw material and tablet dosage forms. International Current Pharmaceutical Journal 2015; 4(6): 390-95.

6. Sivasubramanian L and Lakshmi KS: Spectrophotometric multicomponent analysis of Telmisartan, Hydrochlorothiazide and ramipril in pharmaceutical formulations by chemometric techniques 4(3), 536-550.

7. Tamboli AM, Jamadar MJ, Khan NI, Manure JY and Bathe RS: UV-Spectrophotometric determination of Telmisartan and Hydrochlorothiazide in combined tablet dosage form using simultaneous equation method. IJAPA 2014; 4(1): 18-22.

8. Venkatesansubramanian and Nagappan K: Analytical method development and validation of Telmisartan and Hydrochlorothiazide in tablets using orthogonal polynomial function method. INT J Phar Pha 5(1), 73-75.

9. Rekhagangola, Kaushik $\mathrm{S}$ and Sharma P: Spectrophotometric simultaneous determination of Hydrochlorothiazide and Telmisartan in combined dosage form. Journal of Applied Pharmaceutical Science 2011; 01 (01): 46-49.

10. Ilango K and Shijikumar PS: Simultaneous estimation of Telmisartan and Hydrochlorothiazide in pharmaceutical dosage form. Asian journal of pharmaceutical and health sciences, 2011, 1(1).

11. Lakshmi KS and Lakshmi S: Design and optimization of a chemometric-assisted spectrophotometric determination of Telmisartan and Hydrochlorothiazide in the pharmaceutical dosage form. J Young Pharm 2010; 2(1), : 85-89

12. Subhashini E and Syamasundhar B: New analytical method development and validation for the simultaneous estimation of Telmisartan and Hydrochlorothiazide in bulk and tablet dosage form using RP-HPLC. Carib J Scitech 2014; 2: 519-29.

13. Megala A, Chenthilnathan and Sathishbabu A: Validated RP-HPLC method for simultaneous determination of Telmisartan and Hydrochlorothiazide in pharmaceutical 
formulation. Int J of Pharm Res \& All Sci 2014; 3(3): 3340.

14. Mukunthakumar N, Rao VS, Abbulu K, Narayana BV and Sukumar I: Development and validation of RP-HPLC method for the simultaneous estimation of Telmisartan and Hydrochlorothiazide in bulk and pharmaceutical dosage form. IJPSR 2014; 5(10).

15. Patel $\mathrm{AB}$ and Captain $\mathrm{AD}$ : RP-HPLC method for simultaneous estimation of Telmisartan and Hydrochlorothiazide in API and dosage form. Indo American Journal of Pharmaceutical Research 2014.

16. Varma DP, Ro AL and Dinda SC: Stability indicating RPHPLC method for simultaneous determination of Telmisartan and Hydrochlorothiazide in pharmaceutical dosage form. IJPCBS 2012; 2(3): 382-91.

17. Rote A and Sonavane P: Development and validation of bioanalytical method for determination of Telmisartan and Hydrochlorothiazide using HPTLC in human plasma. American J of Analytical Chemistry 2012; 3: 774-78.

18. Swamy TG, Nagaraju K and Rao AL: RP-HPLC method for the simultaneous estimation of Telmisartan and
Hydrochlorothiazide in pharmaceutical dosage form. International Journal of Drug Development \& Research, $2011 ; 3(4)$.

19. Salama I: Simultaneous HPLC-UV analysis of Telmisartan and Hydrochlorothiazide in human plasma, Bulletin of faculty of pharmacy. Cairo University 2011; 49: 19-24.

20. Bhatia NM, Shinde HV, Bhatia MS, Choudhari PB and Ingale KB: Development and validation of spectrophotometric and ion pair chromatographic techniques for estimation of Telmisartan and Hydrochlorothiazide. ARS Pharm 2010; 51(3): 145-54.

21. Nikolic G: Fourier transforms-new analytical approaches and FTIR strategies. USA: In tech publishers 2011.

22. Validation of analytical procedures: text and methodology Q2 (R1), ICH harmonized tripartite guideline, international conference on harmonization of technical requirements for registration of pharmaceuticals for human use, Nov 2005.

23. Khan and Khanum. Fundamentals of Biostatistics. $3^{\text {rd }}$ edition. Hyderabad: Ukaaz Publications; 2008.

How to cite this article:

Padmavathi Y, Chilka R and Tummala R: Development and validation of FTIR spectroscopic method for simultaneous estimation of telmisartan and hydrochlorothiazide in pure and pharmaceutical dosage forms. Int J Pharm Sci \& Res 2020; 11(2): 862-72. doi: 10.13040/IJPSR.0975-8232.11(2).862-72.

All $\odot 2013$ are reserved by the International Journal of Pharmaceutical Sciences and Research. This Journal licensed under a Creative Commons Attribution-NonCommercial-ShareAlike 3.0 Unported License

This article can be downloaded to Android OS based mobile. Scan QR Code using Code/Bar Scanner from your mobile. (Scanners are available on Google Playstore) 